tigating some properties of D-glucose and choline transport systems. Bichim Biophys Acta 506:136

15. Lebenthal E 1975 Cow's milk protein allergy. Pediatr Clin N Am 22:827

16. Lebenthal E, Lee PC 1983 Interactions of determinants in the ontogeny of the gastrointestinal tract: a unifed concept. Pediatr Res 17:19

17. Lowry OH, Rosebrough NJ, Farr AL, Randall RJ 1951 Protein measurement with the Folin phenol reagent. J Biol Chem 193:262

18. MacKenzie NM, Morris B, Morris R 1983 Protein binding to brush borders of enterocytes from the jejunum of the neonatal rat. Biochim Biophys Acta 755:205

19. Mahmood A, Torres-Pinedo R 1983 Postnatal changes in lectin binding to microvillus membranes from rat intestine. Biochem Biophys Res Commun 113:400

20. Markwell MAK, Fox CF 1978 Surface-specific iodination of membrane proteins of viruses and eucaryotic cells using 1,3,4,6-tetrachloro-3 $\alpha, 6 \alpha$-diphenylglycoluril. Biochemistry 17:4807

21. Moog F 1979 The differentiation and redifferentiation of the intestinal epithelium and its brush border membrane. CIBA Found Symp 70:31

22. Pang KY, Bresson JL, Walker WA 1983 Development of the gastrointestinal mucosal barrier. Evidence for structural differences in microvillus membranes from newborn and adult rabbits. Biochim Biophys Acta 727:201

23. Pang KY, Bresson JL, Walker WA 1983 Development of the gastrointestinal mucosal barrier. V. Comparative effect of calcium binding on microvillus membrane structure in newborn and adult rats. Pediatr Res 17:856

24. Reinhardt MC, Paganelli R, Levinsky RJ 1983 Intestinal antigen handling at mucosal surfaces in health and disease: humabn and experimental studies. Ann Allergy 51:311

25. Roberton DM, Paganelli R, Dinwiddie R, Levinsky RJ 1982 Milk antigen absorption in the preterm and term neonate. Arch Dis Child 57:369

26. Schmitz J, Preiser J, Maestracci D, Ghosh BK, Cerda JJ, Crane RK 1973 Purification of the human intestinal brush border membrane. Biochim Biophys Acta 323:98
27. Seetharam B, Yeh KY, Moog F, Alpers DH 1977 Development of intestinal brush border membrane proteins in the rat. Biochim Biophys Acta 470:424 28. Smithson KW, Millar DB, Jacobs LR, Gray GM 1981 Intestinal diffusion barrier: unstirred water layer or membrane surface mucous coat: Science 214:124

29. Stern M, Walker WA 1984 Food proteins and gut mucosal barrier. I. Binding and uptake of cow's milk proteins by the adult rat jejunum in vitro: Am J Physiol 246:G556

30. Strobel S, Mowat A, Drummond HE, Ferguson A 1981 Age at first feed influences immune response to fed antigen in mice. Pediatr Res 15:1193

31. Svanborg Eden C. Anderson B, Hagberg L, Hanson LA, Leffler J, Magnusson G, Moori G, Dahman J, Soderstrom T 1983 Receptor analogues and antipili antibodies as inhibitors of bacterial attachment in vivo and in vitro. Ann NY Acad Sci 409:580

32. Telemo E, Westrom BR, Karlsson BW 1982 Proteolytic activity as a regulator of the transmission of orally fed proteins from the gut to the blood serum in the suckling rat. Biol Neonate $41: 85$

33. Udall JN, Pang K, Fritze L, Kleinman R, Walker WA 1981 Development of gastrointestinal mucosal barrier. I. The effect of age on intestinal permeability to macromolecules. Pediatr Res 15:241

34. Walker WA, Cornell R, Davenport LM, Isselbacher KJ 1972 Macromolecular absorption. Mechanism of horseradish peroxidase uptake and transport in adult and neonatal rat intestine. J Cell Biol 54:195

35. Walker WA, Isselbacher KJ, Bloch KJ 1974 Immunologic control of soluble protein absorption from the gut small intestine: a gut-surface phenomenon. Am J Clin Nutr 27:1434

36. Wilson TH, Wiseman G 1954 The use of sacs of everted small intestine for the study of the transference of substances from the mucosal to the serosal surface. J Physiol 123:116

37. Wolf JL, Kauffman RS, Finberg R, Dambrauskas R, Fields BN, Trier JS 1983 Determinants of reovirus interaction with the intestinal $M$ cells and absorptive cells of murine intestine. Gastroenterology 85:291

\title{
Lipases and Lipids in Human Milk: Effect of Freeze-Thawing and Storage
}

\author{
SUSAN E. BERKOW, LOIS M. FREED, MARGIT HAMOSH, JOEL BITMAN, D. LARRY WOOD, \\ BARBARA HAPP, AND PAUL HAMOSH
}

Department of Pediatrics and Physiology and Biophysics, Georgetown University Medical Center, Washington, D. C. 20007 [S.E.B., L.M.F., M.H., B.H., P.H.], and Milk Secretion and Mastitis Laboratory, United States Department of Agriculture, Beltsville Agricultural Research Center, Beltsville, MD 20705 [J.B., D.L.W.]

\begin{abstract}
Frozen storage is often used by milk banks to preserve expressed human milk for later use. Optimal storage and handling conditions which ensure minimum alteration of lipid composition have not been well defined. Therefore we investigated the effect of rapid freeze-thawing and storage conditions $\left(-20\right.$ and $\left.-70^{\circ} \mathrm{C}\right)$ on the free fatty acid (FFA) levels and on the activities of lipoprotein lipase (LPL) and bile salt-stimulated lipase (BSSL) in human milk. Since during mechanical expression leakage of serum components into milk may occur, we also investigated the effect of the presence of serum on human milk LPL during storage. Lipase activity levels were unaffected by rapid freeze-thawing $(\times 3)$ followed by storage for 1 month at -20 or $-70^{\circ} \mathrm{C}$. LPL activity (nmol FFA released $/ \mathrm{ml} \mathrm{milk/}$
\end{abstract}

Received January 13, 1984; accepted May 22, 1984

Correspondence may be addressed to Dr. Margit Hamosh, Department of Pediatrics, Georgetown University Medical Center, 3800 Reservoir Road N. W., Washington, D. C. 20007.

This study was supported by National Institutes of Health Contract HD-2-2816. $\min )$ was $414 \pm 128,451 \pm 37$, and $351 \pm 20$ and BSSL activity $(\mu \mathrm{mol}$ FFA/ml milk/min) was $5.7 \pm 0.7,5.5 \pm 0.8$, and $5.7 \pm 0.2$ in fresh, freeze-thawed, and stored milk, respectively. FFA levels (\% of total lipid) were $3.01 \pm 1.05$ and $10.3 \pm 1.6$ in fresh-frozen milk stored at -70 and $-20^{\circ}$ $C$ for 5 months, and $3.78 \pm 1.08$ and $13.60 \pm 1.25$ in specimens of freeze-thawed $(\times 3)$ before storage at -70 or $-20^{\circ} \mathrm{C}$. Addition of serum had no effect on milk LPL at either temperature. We conclude that LPL and BSSL remain fully active during frozen storage of human milk and that milk fat is hydrolyzed at $-20^{\circ} \mathrm{C}$ but not at $-70^{\circ}$ C. We suggest that banked human milk be stored routinely at $-70^{\circ}$ C. (Pediatr Res 18:1257-1262, 1984)

\section{Abbreviations}

BSSL, bile salt-stimulated lipase LPL, lipoprotein lipase FFA, free fatty acids 
Expressed breast milk is widely used to serve the needs of the premature, small for gestational age, and normal term infants who may be ill and cannot suckle. The use of expressed human milk poses specific problems regarding handling procedures. Heating and pasteurization of raw milk may damage the biologically active components of breast milk $(6,19,28)$ and are therefore inadvisable $(1,25)$. Recently, frozen storage has been suggested as a suitable method to preserve expressed breast milk for later usage $(13,14,25)$.

The stability of milk fat during cold storage has been of significant concern to the dairy industry (23); however, until recently, less attention has been focused on lipolysis of stored human milk. Human milk contains two different lipases, BSSL (12) and LPL (17), whereas bovine milk contains only LPL. BSSL leads, after its activation by bile salts in the intestine of the newborn, to complete hydrolysis of triglycerides $(11,18)$. Serum activated lipoprotein lipase, however, has no known function in neonatal digestion $(15,18,20)$. Numerous studies with bovine milk have suggested that the serum stimulated lipoprotein lipase may be responsible for lipolysis and the subsequent rancidity encountered during storage (23).

Recently, it has been suggested that the spontaneous lipolysis observed in bovine milk may be due to serum components leaking into the milk $(7,24)$. It is possible that leakage of serum components into expressed human milk may similarly be responsible for spontaneous lipolysis during storage (5).

The aim of the present study was to determine the effect of storage conditions on human milk lipases and milk lipids. The effect of repeated rapid freezing and thawing on milk LPL and BSSL activity was measured. The effect of storage (at -20 and $-70^{\circ} \mathrm{C}$ ) after repeated freezing-thawing on the lipases of human milk was also evaluated. In addition, we investigated the effect of the presence of serum during storage of human milk on the activity of LPL.

The hydrolysis of milk triglycerides and the accumulation of FFA were also measured under these storage conditions.

\section{MATERIALS AND METHODS}

Milk samples were obtained from donors 3 days to 6 months postpartum. All donors to the Georgetown University Milk Bank are women who produce milk in excess of their infants' needs, and are therefore, in general, excellent producers. The entire content of one breast was expressed with an Egnell mechanical breast pump (Egnell Inc., Cary, IL) between midnight and 0800 either prior to suckling or immediately following nursing from the other breast. All milk specimens were transported to the milk bank on ice and were stored in polypropylene containers at $4^{\circ} \mathrm{C}$ for 1-3 $\mathrm{h}$ until aliquots were taken for analysis.

Freeze-thaw studies. The experimental design is described in Table 1. Fifty-microliter aliquots of fresh milk were immediately extracted by the method of Dole and Meinertz (9) and stored at $4^{\circ} \mathrm{C}$ for $24 \mathrm{~h}$ until lipid analysis was performed. Additional fresh aliquots were taken and stored on ice for immediate enzyme assay. The remainder of the milk sample was frozen rapidly in a mixture of dry ice and acetone followed by rapid thawing under cold water. This procedure (rapid freezing-thawing) was repeated 2 more times, and all samples were then immediately assayed for LPL and BSSL activity by methods described previously (21).

Briefly, BSSL was measured using a long chain triglyceride substrate, glyceryl $\left[9,10-{ }^{3} \mathrm{H}\right]$ oleate. A stable preparation of the triglyceride was made by emulsification of the labeled $(10 \mu \mathrm{Ci})$ and carrier triolein $(25 \mathrm{mg}$ ) in a mixture of $1.5 \mathrm{ml}$ of $1 \mathrm{M}$ Tris$\mathrm{HCl}$ buffer, $\mathrm{pH} 9.0$, and $1.2 \mathrm{ml}$ of $10 \%$ gum arabic (18). Emulsification was carried out with a Polytron PCU-2-110 Sonifier (Brinkmann Instruments, Inc., Westbury, NY) at setting 10 for two periods of $60 \mathrm{~s}$.

The assay system contained in a final volume of $200 \mu \mathrm{l}: 60$ $\mathrm{mM}$ Tris- $\mathrm{HCl}$ buffer, $\mathrm{pH} 9.0,2.8 \%$ bovine serum albumin, $\mathrm{pH}$ 7.4, $1.7 \mathrm{mM}$ triglyceride, $12 \mathrm{mM}$ sodium taurocholate, and 50
Table 1. Experimental design

\begin{tabular}{|c|c|c|c|c|}
\hline \multirow[b]{3}{*}{ Milk treatment* } & \multicolumn{4}{|c|}{ Milk specimen analysis $\dagger$} \\
\hline & \multicolumn{2}{|c|}{ Immediate } & \multicolumn{2}{|c|}{ After storage } \\
\hline & Lipid & Lipases & $-20^{\circ} \mathrm{C}$ & $-70^{\circ} \mathrm{C}$ \\
\hline $\begin{array}{c}\text { None (Fresh Milk) } \\
\downarrow\end{array}$ & $50 \mu \mathrm{l}$ & $200 \mu \mathrm{l}$ & $500 \mu \mathrm{l}$ & $500 \mu l$ \\
\hline $\begin{array}{c}\text { 1st Freezing \& Thawing } \\
\downarrow\end{array}$ & $50 \mu \mathrm{l}$ & $200 \mu \mathrm{l}$ & $500 \mu 1$ & $500 \mu 1$ \\
\hline $\begin{array}{c}\text { 2nd Freezing \& Thawing } \\
\downarrow\end{array}$ & $50 \mu \mathrm{l}$ & $200 \mu \mathrm{l}$ & $500 \mu \mathrm{l}$ & $500 \mu \mathrm{l}$ \\
\hline 3rd Freezing \& Thawing & $50 \mu \mathrm{l}$ & $200 \mu \mathrm{l}$ & $500 \mu \mathrm{l}$ & $500 \mu \mathrm{l}$ \\
\hline
\end{tabular}

* The milk specimens were frozen rapidly in a mixture of dry ice and acetone followed by rapid thawing under cold water.

$\dagger$ Specimens were analyzed immediately (on the day of the experiment) or after storage at -20 and $-70^{\circ} \mathrm{C}(1$ month for lipase and 5 months for lipid quantitation).

$\mu \mathrm{l}$ diluted milk. Milk was diluted 1:100-1:200 in $5 \mathrm{mM}$ veronal buffer, $\mathrm{pH}$ 7.4. Incubation was at $37^{\circ} \mathrm{C}$ for $15 \mathrm{~min}$ in a Dubnoff shaking bath. The reaction was stopped by the addition of 3.25 $\mathrm{ml}$ of a mixture of methanol:chloroform:heptane (1.41:1.25:1.0, $\mathrm{vol} / \mathrm{vol} / \mathrm{vol}$ ). Free fatty acids were separated from the unhydrolyzed substrate by addition of $1.05 \mathrm{ml}$ of $0.05 \mathrm{M}$ potassium carbonate buffer, $\mathrm{pH} 10$. One-half milliliter of the aqueous phase was transferred to $5.0 \mathrm{ml}$ of Readi-Solu MP scintillation fluid (Beckman Inst., Inc., Fullerton, CA), and the radioactivity was quantitated using internal standards for quench correction. Of the total free fatty acids, $70 \%$ were present in the alkaline upper phase. Mixtures of nonradioactive triglyceride emulsion and $\left[{ }^{3} \mathrm{H}\right]$ oleic acid were used to determine the partition coefficient of free fatty acids in the two phases.

LPL activity was measured by hydrolysis of serum activated tri $\left[9,10-{ }^{3} \mathrm{H}\right]$ oleate emulsion. The assay system contained in a final volume of $200 \mu \mathrm{l}: 200 \mathrm{mM}$ Tris- $\mathrm{HCl}$ buffer, $\mathrm{pH} 8.6,5 \%$ bovine serum albumin, $3 \mathrm{mM}$ triglyceride, 0.25 unit heparin, and $10-20 \mu \mathrm{l}$ undiluted milk. Incubation was at $37^{\circ} \mathrm{C}$ for $15-30$ min in a Dubnoff shaking bath. The reaction was stopped and the free fatty acids were isolated and quantitated as described for the BSSL.

Additional samples were repeatedly frozen and thawed three times, as just described, and were then stored frozen $(-20$ to $-70^{\circ} \mathrm{C}$ ) for 1 month, at which time lipase activities were quantitated. The lipid composition of the fresh milk specimens, of specimens taken immediately following freezing and thawing, and after 5 months of storage was determined by quantitative densitometry in situ, using the Shimadzu dual wavelength TLC scanner (Shimadzu Scientific Instruments Inc., Columbia, MD). Samples were separated and charred prior to scanning by a slight modification of the method of Bitman and Wood $(3,4)$. Samples were applied onto Merck $20 \times 20 \mathrm{~cm}$ silica gel plates and developed in a saturated tank containing a mixture of petroleum ether:anhydrous ethyl ether:glacial acetic acid (144:70:1.2). Following development, the plates were dried, dipped in a mixture of $10 \%$ cupric sulfate in $8 \%$ phosphoric acid, and then charred in a conventional oven at $210^{\circ} \mathrm{C}$ for $10 \mathrm{~min}$.

Duplicate samples from randomly selected milk specimens (fresh and after one, two, or three freeze-thawing cycles) agreed in lipid and lipase values within $<6 \%$, suggesting adequate mixing of all specimens prior to aliquoting.

Effect of serum during milk storage. Because lipoprotein lipase is activated by a specific serum protein (apoprotein C-II) (2), we have tested whether the lipase might be activated and hydrolyze milk lipid during storage in the presence of serum. The rationale for this experiment is the need for only small amounts of serum apoprotein C-II (such as might be present in milk from slight nipple abrasions) for activation of lipoprotein lipase. 
One hundred microliters or $200 \mu \mathrm{l}$ of inactivated human serum [heated for $10 \mathrm{~min}$ at $60^{\circ} \mathrm{C}$ to inactivate lipase activity (8)] were added to $1.0-\mathrm{ml}$ samples of fresh human milk before storage at -20 and $-70^{\circ} \mathrm{C}$ for 2 to $12 \mathrm{wk}$. At 2,4 , and $12 \mathrm{wk}$, LPL activity and the extent of triglyceride hydrolysis were determined. Triglycerides were quantitated by the hydroxamic acid method of Rapport and Alonzo (22) and FFA were determined by microtitration (9).

The samples analyzed at 2 and $4 \mathrm{wk}$ were thawed one time only, immediately prior to analysis; the samples analyzed at 12 wk were thawed and refrozen at 1 month of storage and were then thawed once more immediately before analysis in order to assess the effect of freezing and thawing on further storage of these specimens. The times $(2,4$, and $12 \mathrm{wk})$ chosen were those of general storage of banked human milk specimens.

\section{RESULTS}

The effect of quick freezing and thawing on the activity of bile salt-stimulated lipase and lipoprotein lipase in human milk is shown in Figure 1. Our data show that repeated rapid freeezingthawing had no effect on BSSL activity. Although there was a slight decrease in LPL activity, it was not significant. The data further suggest that the lipases are equally stable in transitional and mature milk. Although there was a wide range of LPL activity in the milk studied (10-700 nmol FFA $/ \mathrm{ml} / \mathrm{min}$ ), our data show that this enzyme is equally stable in milk with high and low activity levels. The wide variability in LPL activity is a function of interindividual differences (Fig. $1 A$ ).

The effect of storage for 1 month (at -20 and $-70^{\circ} \mathrm{C}$ ) after rapid freezing-thawing on the lipases of human milk is shown in Figure 2. After storage for 1 month at -20 and $-70^{\circ} \mathrm{C}$, the LPL activity in milk which was fresh-frozen was slightly, though not significantly, reduced compared to the activity measured in the fresh milk. LPL activity measured in milk which had been repeatedly frozen and thawed was also slightly, however not significantly, lower than the activity measured immediately after rapid freezing-thawing. In all cases, the LPL activity of milk stored for 1 month at $-70^{\circ} \mathrm{C}$ was higher than the activity in milk stored at $-20^{\circ} \mathrm{C}$ (Fig. $2 A$ ).

In contrast, there was no difference in BSSL activity in the stored milk when compared to fresh milk (Fig. $2 B$ ). Furthermore, storage temperature $\left(-20\right.$ or $\left.-70^{\circ} \mathrm{C}\right)$ had no effect on the activity of this enzyme during the time period studied.

The change in the triglyceride concentration of milk which had been repeatedly frozen and thawed was not greater than $5 \%$ of that of fresh milk (Fig. 3). When the milk specimens were stored for 5 months, the triglyceride concentration decreased by 10 and $13 \%$ in milk stored at $-20^{\circ} \mathrm{C}$, immediately or after repeated freeze-thawing, respectively; there was no decrease in the triglyceride content of milks stored at $-70^{\circ} \mathrm{C}$ (Fig. 3). Concomitantly with the decrease in milk triglyceride levels during storage at $-20^{\circ} \mathrm{C}$, the free fatty acid content increased to 10 and $13.6 \%$ in milk stored immediately or after three freezing and thawing cycles; monoglycerides were undetectable in fresh milk, but increased to $1.30 \%$ after repeated freezing and thawing and storage at $-20^{\circ} \mathrm{C} ;$ no monoglycerides were detected in specimens stored at $-70^{\circ} \mathrm{C}$. Diglycerides increased slightly during freezethawing $(0.47 \%$ in fresh milk and $0.60 \%$ after three times freezing and thawing) and increased further during storage at $-20^{\circ} \mathrm{C}$ to $1.30 \%$ of total lipid. Free fatty acid and partial glyceride levels changed only minimally in milk specimens stored at $-70^{\circ} \mathrm{C}$.

Apoprotein C-II, a component of human serum, is the specific activator of LPL. We have therefore measured the effect of serum on LPL activity during storage of milk specimens for up to 12 wk. The data are presented in Figure 4. Preliminary data in our laboratory have shown that milk LPL is stable for up to 6 months when milk specimens are stored at $-70^{\circ} \mathrm{C}$. We therefore have compared the lipase activity in milks stored for $2-12$ wk with and without serum. Our data suggest that the addition of $100 \mu \mathrm{l}$

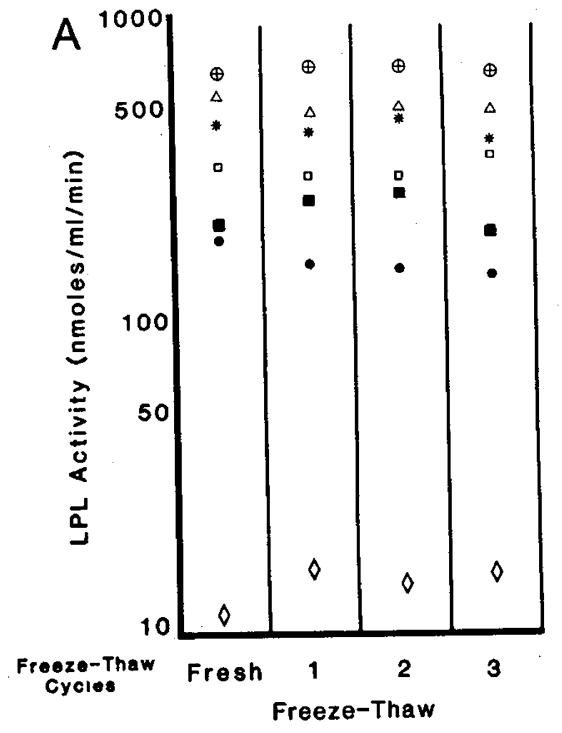

$\oplus \Delta * 0 \cdot 2-3$ Months

$\checkmark 12$ Days

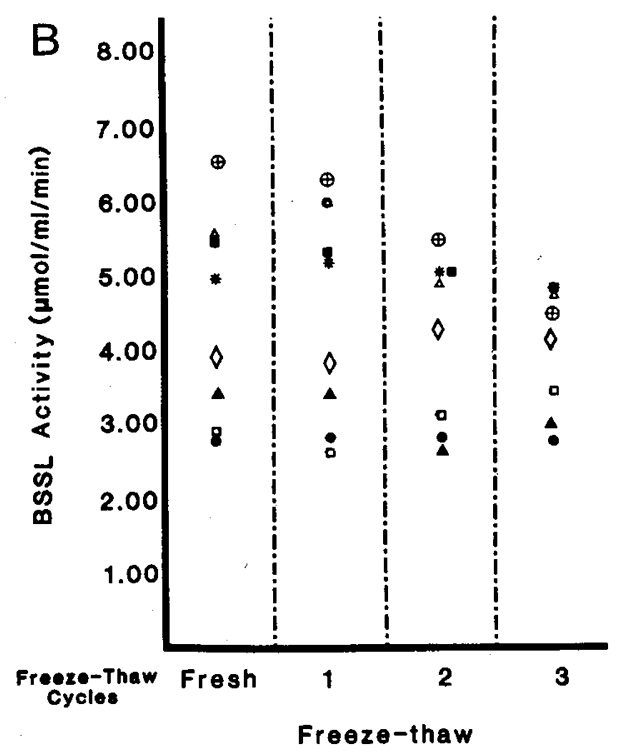

Fig. 1. Effect of freeze-thawing $(\times 3)$ on the activity of $(A) \mathrm{LPL}$ and $(B)$ BSSL. Individual data for seven (LPL) and eight milk specimens (BSSL). Samples are represented by the same symbol in panels $A$ and $B$. The additional milk specimen in Figure $2 B(\boldsymbol{\Lambda})$ is mature milk.

inactivated human serum to $1 \mathrm{ml}$ milk does not change the LPL activity when compared to the LPL activity in milk stored for the same time period without serum. Storage of the milk specimens with $200 \mu 1$ of serum lowered slightly LPL activity, although the decrease was not significant. Similar results were obtained whether the milk was stored at -20 or $-70^{\circ} \mathrm{C}$. The LPL activity in milk stored with or without serum was slightly, but not significantly, higher at 4 than at $2 \mathrm{wk}$.

After 12 wk of storage at -20 and $-70^{\circ} \mathrm{C}$, there was little change in milk LPL activity in samples stored with and without serum. Furthermore, freezing and thawing once prior to storage appeared to have no effect on the LPL activity in milk stored for up to 12 wk.

Addition of increasing amounts of serum to milk had little effect on the hydrolysis of milk fat in samples stored for 2,4 , or $12 \mathrm{wk}$ (Table 2). The milk analyzed after $12 \mathrm{wk}$ of storage had been previously frozen and thawed once. Up to $30 \%$ hydrolysis 

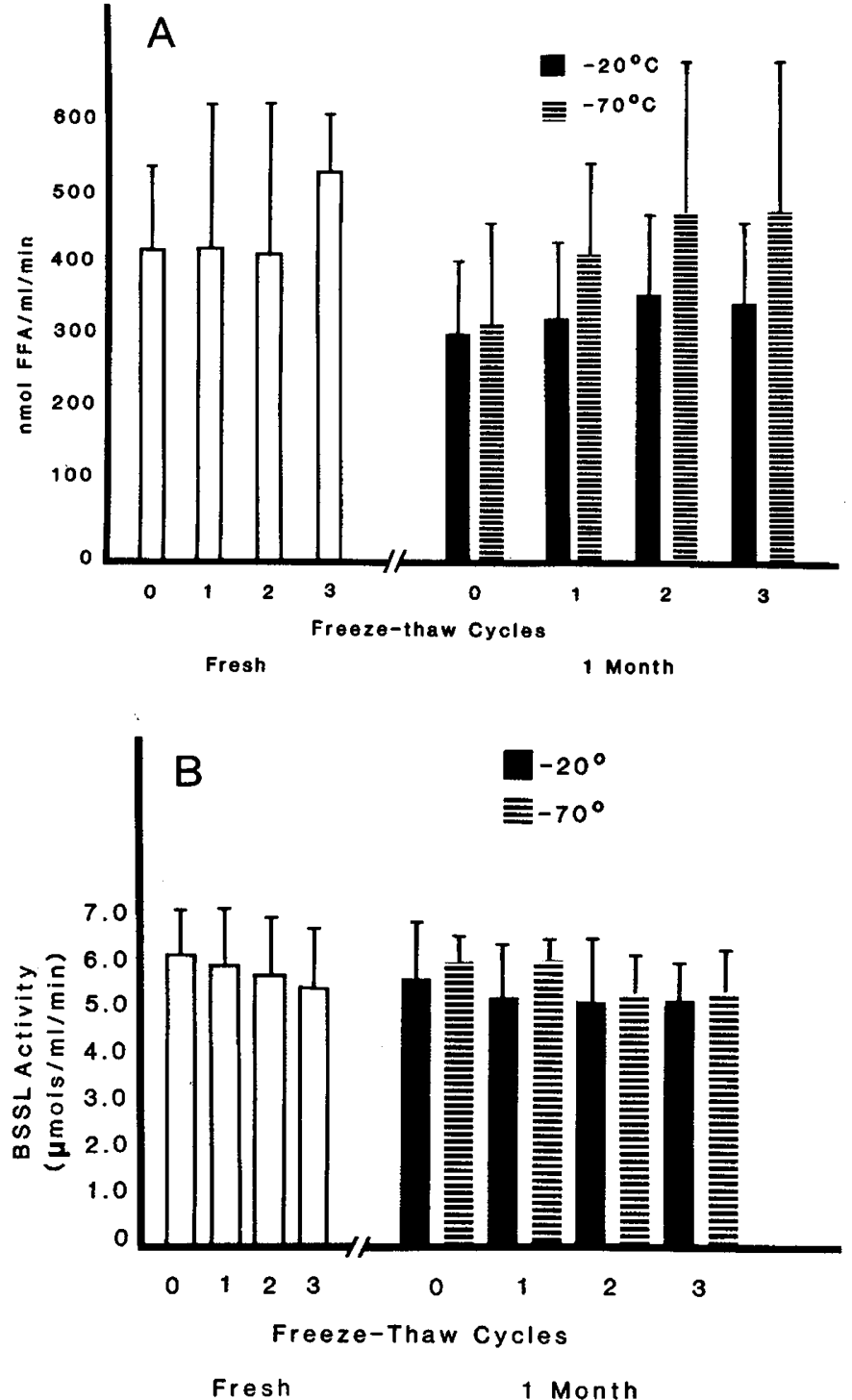

Fig. 2. Effect of freeze-thawing and storage (at -20 or $-70^{\circ} \mathrm{C}$ ) on the activity of $(A)$ lipoprotein lipase and $(B)$ bile salt-stimulated lipase in milk. Specimens were analyzed immediately after repeated freeze-thawing and following 1 month of storage. Data are mean \pm SEM of three milk specimens.

occurred in these milk specimens when stored at $-20^{\circ} \mathrm{C}$, compared with only little hydrolysis when stored at $-70^{\circ} \mathrm{C}$. The addition of serum to milk before storage had no effect on triglyceride hydrolysis, whereas freezing and thawing once increased the extent of fat hydrolysis during storage of milk at $-20^{\circ}$ $\mathrm{C}$, with and without serum.

\section{DISCUSSION}

The effect of storage conditions and handling of banked human milk, and the changes that may take place in nutrient composition and/or bioavailability have recently been investigated $(13,14,27)$. In this study, we have examined the effects of temperature and handling on milk lipases and triglyceride hydrolysis.

Our results suggest that rapid freezing-thawing causes no activation or inactivation of milk lipases. BSSL displayed little fluctuation in activity when measured immediately following rapid freezing-thawing or after frozen storage $\left(-20\right.$ and $\left.-70^{\circ} \mathrm{C}\right)$ for 1 month (Figs. 1 and 2).

In general, LPL exhibits no loss of activity upon repeated freezing and thawing, although there is wide variation in LPL

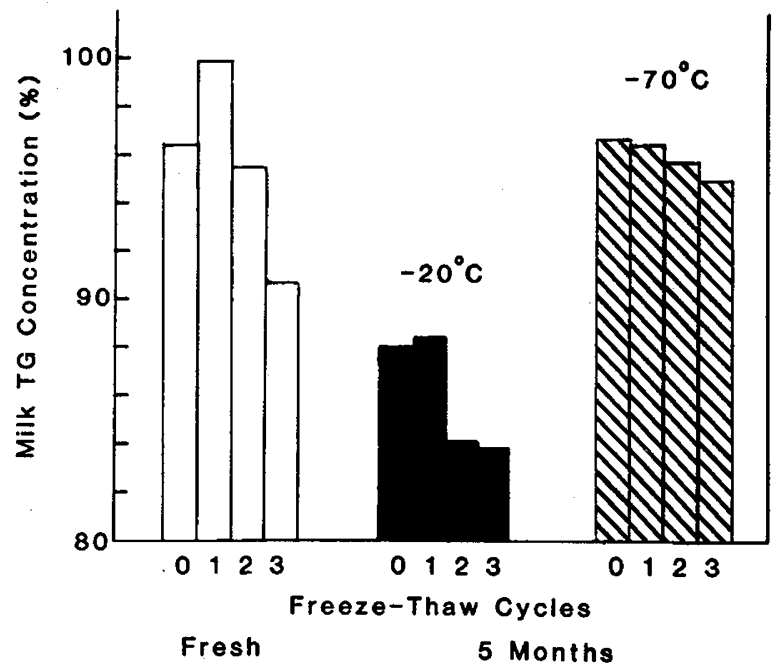

Fig. 3. Effect of storage at -20 or $-70^{\circ} \mathrm{C}$ on the triglyceride $(T G)$ concentration of milk specimens fresh-frozen or stored after repeated $(\times 3)$ freezing and thawing. Data are mean \pm SEM of three specimens of mature milk.

levels in mature milk from different individuals as well as large differences in activity levels from colostrum to mature milk. Since the sampling accuracy is within $6 \%$, this variability is not the result of sampling variation but reflects interindividual differences of LPL activity.

Storage at $-20^{\circ} \mathrm{C}$ for 1 month following repeated quick freezing and thawing may result in a small decrease in LPL activity. Our data show that LPL activity remained stable in milk subjected to repeated freeze-thawing and stored at $-70^{\circ} \mathrm{C}$. Other investigators $(23,26)$ have reported a progressive increase of lipase activity during cold storage. These studies, however, have measured a nonspecific lipase (23), which may not be comparable to LPL.

The milk fat globule is almost completely resistant to lipolysis, as long as its structure remains intact. The freezing and thawing of milk may disrupt the membrane and allow greater access of milk lipases to the triglyceride contained within the core of the fat globule.

The triglyceride concentration of milk which had been rapidly frozen and thawed three times remained stable. It is possible that rapid freezing in a mixture of dry ice and acetone and thawing in cold water caused only minimal disruption of the milk fat globule membrane. It has been reported that, in bovine milk, rapid lipolysis was induced by sonication; however, less dramatic manipulations (such as cooling and rewarming, and addition of albumin or heparin) did not rupture the milk fat globule membrane (2) and lipolysis was not induced. It is also possible that if the milk fat globule membrane was disrupted, but the milk remained at $4^{\circ} \mathrm{C}$ throughout the rapid thawing, no lipolysis occurred. When the triglyceride was measured after 5 months of storage $\left(\right.$ at $-20^{\circ} \mathrm{C}$ ), there was a 13 and $10 \%$ decrease in concentration in freeze-thawed and fresh-frozen milk, respectively. Freezing and thawing prior to storage have been reported to contribute to hydrolysis of triglycerides during storage (5); the milk fat globule membrane lipid components (phospholipids and cholesterol) were, however, unaffected by this treatment (5).

Although human milk contains lipases, there is no spontaneous hydrolysis of milk fat in the mammary gland. This may be explained by the fact that both lipases must be activated by agents not present in milk; BSSL requires bile salts $(11,18)$ and LPL requires apoprotein $C$-II, a serum protein, which facilitates the binding of the enzyme to the lipid substrate $(2,17)$.

During mechanical expression of milk, it is possible that leakage of serum components into milk may occur, LPL may then be provided with the necessary apoprotein to facilitate activity. To test this, in a separate experiment, we stored milk 


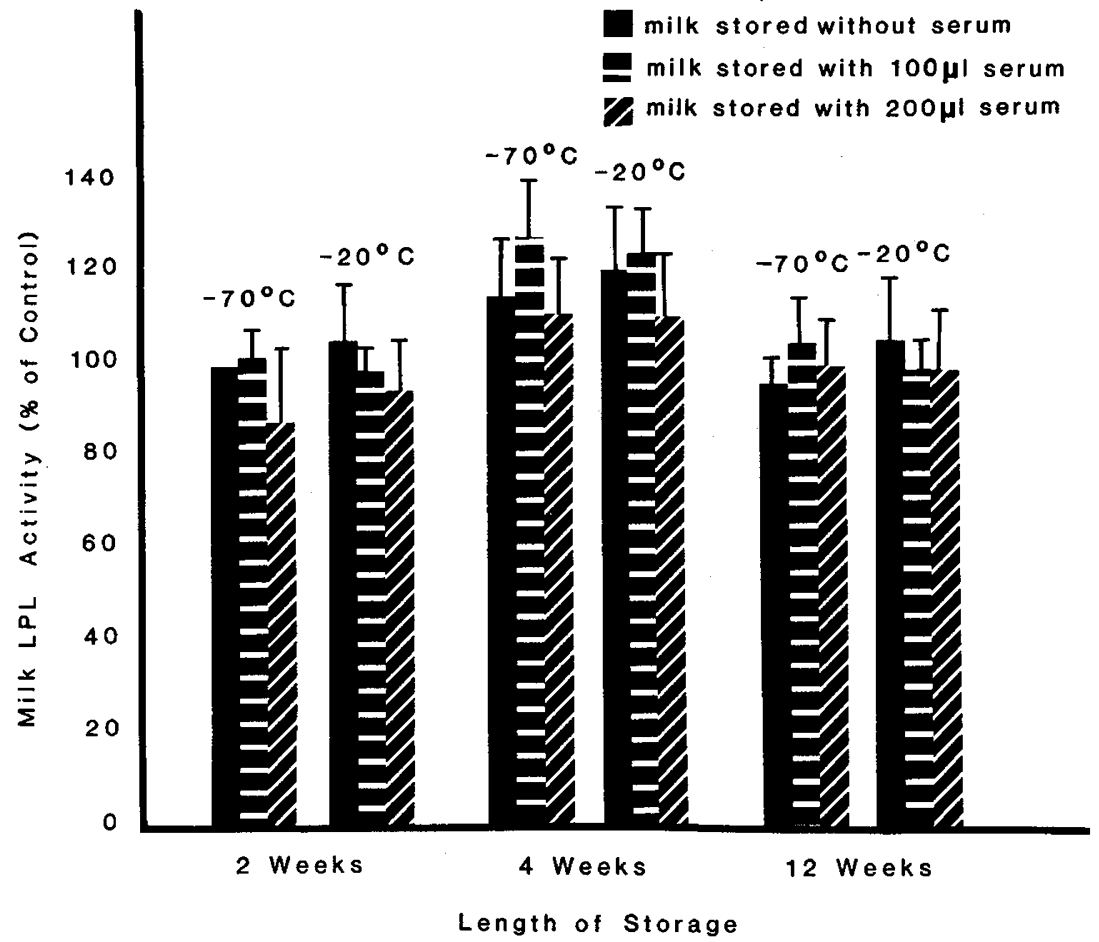

Fig. 4. Effect of storage conditions on lipoprotein lipase activity of human milk. Fresh human milk specimens were mixed with inactivated human serum (which contains apoprotein C-II, an activator of lipoprotein lipase) at a ratio of $6: 1$ and $11: 1$ before storage at -20 and $-70^{\circ} \mathrm{C}$ for 2 , 4 , and 12 wk. Data are mean \pm SEM of five milk specimens.

Table 2. Effect of serum on the hydrolysis of milk triglyceride during storage*

\begin{tabular}{|c|c|c|c|c|c|c|}
\hline & \multicolumn{6}{|c|}{ Storage time } \\
\hline & \multicolumn{3}{|c|}{$-20^{\circ} \mathrm{C}$} & \multicolumn{3}{|c|}{$-70^{\circ} \mathrm{C}$} \\
\hline & 2 wk & $4 \mathrm{wk}$ & $12 \mathrm{wk}$ & $2 \mathrm{wk}$ & $4 \mathrm{wk}$ & $12 \mathrm{wk}$ \\
\hline Serum $(100 \mu \mathrm{l})$ & $2.10 \pm 0.55$ & $1.30 \pm 0.37$ & $22.50 \pm 4.34$ & $1.57 \pm 0.24$ & $1.77 \pm 0.28$ & $2.60 \pm 0.20$ \\
\hline Serum $(200 \mu \mathrm{l})$ & $1.70 \pm 0.75$ & $1.36 \pm 0.29$ & $17.35 \pm 0.48$ & $1.78 \pm 0.38$ & $1.40 \pm 0.38$ & $6.93 \pm 3.30$ \\
\hline
\end{tabular}

${ }^{*}$ Data are $\%$ hydrolysis (mean \pm SEM). The milk specimens were thawed once and immediately refrozen at 4 wk of storage at both -20 and $-70^{\circ} \mathrm{C}$.

samples at -20 and $-70^{\circ} \mathrm{C}$ with varying amounts of inactivated human serum for up to 3 months. Our results suggest that the addition of serum to human milk appears to have no effect on spontaneous lipolysis of milk fat under cold storage conditions. The lack of effect may have been due to the inaccessibility of apoprotein C-II to the lipase, as no mechanical agitation was employed prior to freezing. Sundheim et al. (24) have shown that, in bovine milk, apoprotein C-II must be added to milk prior to mechanical treatment (vortexing) in order to induce an increase in lipolysis. These investigators suggest that a prerequisite for stimulation by apoprotein C-II is a physicochemical alteration of the fat globule which may be mediated through vigorous agitation. The hydrolysis of fat that occurred in milk stored with serum for $12 \mathrm{wk}$ was due to the effect of freezingthawing prior to storage, rather than to the addition of apoprotein C-II (Table 2).

These findings suggest that expressed breast milk may be stored at temperatures below $-20^{\circ} \mathrm{C}$ for up to 3 months with minimum change in lipase activity. Ideally, freezing and thawing of banked human milk prior to storage should be avoided.

LPL and BSSL activities remain stable in milk during freezingthawing and frozen storage. The addition of serum does not stimulate milk LPL activity nor does it enhance hydrolysis. BSSL activity is $10-20$-fold higher in human milk than LPL activity and since it has recently been reported that trace amounts of bile salts are present in human milk (10), it is possible that this lipase may contribute to the triglyceride hydrolysis during storage. A slight increase in the level of free fatty acids (to twice the normal level found in fresh human milk) has been linked to the development of breast milk jaundice in the newborn infant (16). Because of ongoing lipolysis during storage at $-20^{\circ} \mathrm{C}$, human milk might have to be stored at lower temperatures in order to prevent the rise in free fatty acids. Further studies are necessary to clarify the role of milk lipases in the hydrolysis of milk triglyceride during storage.

Acknowledgments. We thank the mothers for their milk donations. The secretarial help of Ms. Marguerite Starry is gratefully acknowledged.

\section{REFERENCES}

1. American Academy of Pediatrics Committee on Nutrition 1980: Human milk banking. Pediatrics 65:854

2. Bengtsson G, Olivecrona T 1982 Activation of lipoprotein lipase by apolipoprotein C-II. Fed Eur Biochem Soc 147:183

3. Bitman J, Wood DL 1981 Quantitative densitometry in situ of lipids separated by thin layer chromatography. J Liquid Chromatogr 4:1023

4. Bitman J, Wood DL 1980 An improved copper reagent for quantitative densitometric thin-layer chromatography of lipids. J Liquid Chromatogr 5:1155

5. Bitman J, Wood DL, Mehta NR, Hamosh P, Hamosh M 1983 Lipolysis of triglycerides of human milk during storage at low temperatures: a note of caution. J Pediatr Gastroenterol Nutr 2:521

6. Bjorksten $\Upsilon$, Burman L, Dechateau P, Fredrikzon B, Grothefors G, Hernell O 1980 Collecting and banking human milk: to heat or not to heat? $\mathrm{Br}$ Med J $281: 765$ 
7. Clegg R 1980 Activation of milk lipase by serum proteins: possible role in the occurrence of lipolysis in raw bovine milk. J Dairy Res 47:61

8. DiCorleto PE, Zilversmit DB 1975 Lipoprotein lipase activity in bovine aorta. Proc Soc Exp Biol Med 148:1101

9. Dole VP, Meinertz H 1960 Microdetermination of long chain fatty acids in plasma and tissues. J Biol Chem 235:2295

10. Forsyth JS, Ross PE, Bouchier IAB 1983 Bile salts in breast milk. Eur J Pediatr 140:126

11. Fredrikzon B, Hernell O, Blackberg L, Olivecrona T 1978 Bile salt stimulated lipase in human milk: evidence of activity in vivo and of a role in the digestion of milk retinol esters. Pediatr Res 12:1048

12. Freudenberg E 1953 Die Frauenmilchlipase. Karger, Basel.

13. Friend BS, Shahani KM, Long CA, Vaughn LA 1983 The effect of processing and storage on key enzymes, B vitamins and lipids of mature human milk. I. Evaluation of fresh samples and effects of freezing and frozen storage. Pediatr Res 17:61

14. Garza C, Johnson CA, Harrist R, Nichols BL 1982 Effects of methods of collection and storage on nutrients in human milk. Early Hum Dev 6:295

15. Hamosh M 1981 Physiological role of milk lipases. In: Lebenthal E (ed) Textbook of Gastroenterology and Nutrition. Raven Press, New York, p 473

16. Hargreaves T 1973 Effect of fatty acids on bilirubin conjugation. Arch Dis Child 48:446

17. Hernell O, Olivecrona T 1974 Human milk lipases. I. Serum-stimulated lipase. J Lipid Res 15:367

18. Hernell O, Olivecrona T 1974 Human milk lipases. II. Bile salt stimulated lipase. Biochem Biophys Acta 369:234

19. Hernell O 1975 Human milk lipases. III. Physiological implications of the bile salt stimulated lipase. Eur J Clin Invest 5:267

20. Hernell O, Blackberg L, Olivecrona T 1981 Human milk lipases. In: Lebenthal E (ed) Textbook of Gastroenterology and Nutrition. Raven Press, New York, p 347

21. Mehta NR, Jones JB, Hamosh M 1982 Lipases in preterm human milk: ontogeny and physiologic significance. J Pediatr Gastroenterol Nutr 1:317

22. Rapport MA, Alonzo N 1959 Photometric determination of fatty acid ester groups in phospholipids. J Biol Chem 217:193

23. Schwartz DP, Parks OW 1974 The lipids of milk: deterioration. In: Webb BH Johnson AH, Alford JA (eds) Fundamentals of Dairy Chemistry. Avi Publishing Co, Inc, Westport, CT, p 220

24. Sundheim T, Zimmer L, Astrup HN 1983 Induction of milk lipolysis by lipoprotein components of bovine blood serum. J Dairy Sci 66:400

25. Sunshine $P 1980$ Human breast milk-storage and safety considerations. Western J Med 132:61

26. Tarassuk NP, Nickerson TA, Yaguchi M 1964 Lipase action in human milk. Nature 201:298

27. Wardell J, Hill C, D'Souza S 1981 Effect of pasteurization and of freezing and thawing human milk on its triglyceride content. Acta Paediatr Scand 70:467

28. Williamson S, Finucane E, Ellis $\mathrm{H}$, Gamsu $\mathrm{H} 1978$ Effect of heat treatment of human milk on absorption of nitrogen, fat, sodium, calcium and phosphorus by preterm infants. Arch Dis Child 53:555

\title{
The Effect of Calcium Antagonists on Hypoxic Pulmonary Hypertension in the Piglet
}

\author{
PAULO J. DICKSTEIN, OSWALDO TRINDADE，RONALD N. GOLDBERG，AND \\ EDUARDO BANCALARI \\ Division of Nêonatology and Department of Pediatrics, University of Miami School of Medicine, Miami, \\ Florida 33101
}

\begin{abstract}
Cardiovascular responses to the calcium antagonists verapamil and nifedipine were evaluated in a piglet model of hypoxic pulmonary hypertension. All animals were mechanically ventilated and paralyzed. Cardiac output (CO), pulmonary artery (Ppa) and aortic blood pressure (AoP), pulmonary wedge pressure, right atrial pressure (Pra), and arterial blood gases were measured prior to and after pulmonary hypertension was induced by hypoxia and after administration of calcium-blocking agents. Results were compared to a control group of piglets subjected to a similar period of hypoxia. Verapamil infusion $(0.15 \mathrm{mg} / \mathrm{kg})$ resulted in a rapid decrease in $\overline{\mathrm{Ppa}}, \overline{\mathrm{AoP}}$ and pulmonary vascular resistance $(p<0.05)$ which returned to baseline values by $15 \mathrm{~min}$. Nifedipine $(100 \mu \mathrm{g} /$ $\mathrm{kg})$ resulted in a decrease in Ppa at $1 \mathrm{~min}(p<0.05)$ which remained significantly lower than controls throughout the study period. AoP declined precipitously during the same time period $(p<0.01)$. No significant change in $\overline{P p a}$ was noted when nifedipine was administered at a dose of $10 \mu \mathrm{g} /$
\end{abstract}

Received August 4, 1983; accepted May 7, 1984

Correspondence may be addressed to Ronald N. Goldberg, M.D., Department of Pediatrics (R-131), University of Miami School of Medicine, P.O. Box 016960, Miami. FL 33101.

This work was supported in part by National Institutes of Health Grants 1RO1 HD14940-03 and 5RO1 HL25023-03, March of Dimes Research Grant 6-303, and University of Miami Project: New Born. kg. For the most part, these drugs have a transient vasodilatory action on pulmonary as well as systemic circulation in this animal model; however, they might in higher doses be associated with significant systemic hypotension. For this reason, the use of these drugs in the treatment of hypoxic pulmonary hypertension in the neonate should be approached with caution. (Pediatr Res 18:1262-1265, 1984)

\section{Abbreviations}

AoP, aortic blood pressure

$\mathrm{CO}$, cardiac output

Ppa, pulmonary artery pressure

Ppaw, pulmonary wedge "ressure

Pra, right atrial pressure

PVR, pulmonary vasculat .esistance

SVR, systemic vascular resistance

Pulmonary hypertension with secondary right to left shunting through the foramen ovale and/or ductus arteriosus is a common problem in the neonatal period. It has been associated with hyaline membrane disease (9), transient tachypnea of the newborn (4), meconium aspiration (8), fetal hypoxia (20, 22), and 